\title{
Identifying as an outsider: implications for nonfamily in small family firms.
}

\author{
CUNNINGHAM, J.
}

2020

This is an Accepted Manuscript of an article published by Taylor \& Francis in International Journal of Human Resource Management on 27.04.2018, available online:

http://www.tandfonline.com/10.1080/09585192.2018.1469160. 


\title{
Identifying as an Outsider: Implications for Nonfamily in Small Family Firms \\ Author accepted manuscript in the International Journal of Human Resource Management
}

\begin{abstract}
Family businesses are held in high regard the world over for their impact on employment, credited in part to their longevity and abundance. In spite of this omnipresence, we have only begun to understand the day-to-day realities of the family business as an employer. In this work, I look to further this understanding by investigating what it means to work for a family business. Nonfamily employees contribute greatly, however, they are not closely coupled to the identity of the family unit. I ask how they see, understand and deal with their identity as outsiders in a close family business. A social constructivist approach is used to paint a picture of how nonfamily identity is formed, using qualitative data and inductive analytical methods. Findings highlight the identity of nonfamily as developed through their relationship with the family business. This relationship is explained as a function of social identity theory and the implications for the family business management are explored.
\end{abstract}

Keywords family business, nonfamily employee, social identity theory, agency, qualitative data

\section{Introduction}

With this article I shed light on an often overlooked arena of HR practice, the small family business. While our understanding of family firms has developed greatly in the past 20 years, the internal characteristics of management and employee relations tend to be overshadowed by more dominant discussions related to the goals of the controlling family. For instance, we often debate the intricacies of the 'family effect' on strategic issues such as governance and succession (Gilding et al., 2015) and their impact on firm performance. By maintaining this strategic focus, the family business literature has uncovered various aspects considered to be 
uniquely 'familial'. Many paint a picture of a close-knit family firm which prioritises nonfinancial goals (Zellweger et al., 2013), takes pride in collective commitment (Kotlar \& De Massis, 2013) and actively builds reputable community-engagement through the generation of socioemotional wealth (Deephouse \& Jaskiewicz, 2013). Perhaps there can be little wonder why family firms enjoy something of a moral high ground in society's perception of the business world (Dyer \& Whetten, 2006).

However, it is not only in their strategic development and community embeddedness that family firms contribute to society, they are also substantial employers. For instance, the Institute for Family Business (IFB Research Foundation, 2016) claims that $47 \%$ of all private sector employment in the UK are generated by family-controlled businesses, a trend supported by the Department for Business Innovation \& Skills (2015) when they report $72 \%$ of all SME employers defined as family-owned businesses. Despite such importance to the employment structure of the economy, a key struggle for family firms is found in attracting and maintaining a skilled workforce (Mandl, 2008). A report compiled for the European Commission (2009) suggests that, while family influence is an asset in relations with partners and clients, for the labour market there can be negative perceptions of paternal and nepotistic behaviours limiting career opportunities. In practice too, firms themselves find they must consider the crucial challenges of managing people in the context of family influence. PWC (2016) find 48\% of family firms feel they have to work harder than nonfamily counterparts to retain top talent, while KPMG (2017) similarly report recruitment as a key family firm anxiety.

One explanation for the concern around family firms as employers may be their rather idiosyncratic approach to management practices (Mitchell et al., 2003) and perspectives on the socialization of nonfamily employees (Tabor et al., 2018). When many organisational members are directly related, either through blood or marriage lines, there is less perceived requirement to follow standardised and informed methods of evidence-based management (Briner et al., 
2009). Kim and Gao (2010) find the informal HRM practices of small family firms affords them a flexibility to respond to managerial issues in a more reactive fashion (de Kok et al., 2006). For example, in lieu of formal appraisal and merit-based systems of progression, family firms may rely on nepotism, even primogeniture, to hasten managerial decision-making (Jaskiewicz et al., 2013; Reid \& Adams, 2001). However, current perspectives on family firms as employers are fragmented and present a mixed view on the benefits of family involvement (Chrisman et al., 2005; Sánchez-Marín et al., 2017). While socioemotional wealth can be maintained more easily through closed communication channels and limited employee engagement (Fang et al., 2017; Harris et al., 2004;), this is often coupled with calls for family firms to enhance opportunity for broader employee participation, in order to bolster performance (Bello-Pintado \& Garcés-Galdeano, 2017; Madison et al., 2018). Instead of focus on such output-driven interpretations, I turn attention to what family influence means for the employee of the firm, as this may help explain the challenges family firms face in finding and retaining staff. Specifically I ask, with such informal and closely held family dynamics in the family firm, where does this leave the nonfamily employee?

Adopting social identity theory as a conceptual lens (Tajfel \& Turner, 1985), I extend the identity perspective in family business by shifting focus away from the family unit and illuminating identity formation in nonfamily employees. Essentially, I seek to uncover how nonfamily employees make sense of their employment experiences (Whetten et al., 2014). In order to achieve this, I follow Ellemers et al. (2002) and examine two distinct but related elements of the identity perspective: the strength of nonfamily association with the family firm as a social category and the content of nonfamily identity as constructed by the individual nonfamily employee and the controlling family.

Combined, these two components of nonfamily social identity allow us to investigate a contextually-informed and critically-reflective employee identity, an identity which represents 
a substantial part of the national workforce (Bjuggren et al., 2011). This paper contributes to both the HRM and family business literatures by questioning the unchallenged reliance on family identity as a positive motivator and behavioural regulator. Conclusions provide implications for HRM in family businesses, and in all organisations where one social identity dominates.

\section{Background}

\section{Dominant family identity}

In family firms, the unifying nature of family relations produces a dominant identity which reaches into all aspects of organisational life (Zellweger et al., 2010). The family serves to draw the central character of the organisation, based on shared values, beliefs and norms (Albert \& Whetten, 1985). As such, the integration of family and business systems may skew towards family identity as a blueprint upon which to base organisational identity (Barnett et al., 2009). Common histories and shared experiences of family members provide an organisational distinctiveness so acute that it can be seen as an extension of the family itself (Schmidts \& Shepherd, 2013; Sundaramurthy \& Kreiner, 2008).

When a family dominants organisational identity, internal cultural behaviours and values tend to closely reflect how the firm has behaved in the past (Gagné et al., 2014; Le Breton-Miller \& Miller, 2008). Zellweger et al. (2012) explain that production of norms and values over time build a cultural resource for the family firm, where familial actions of the past connect directly to business actions of the present. While this may raise claims of path dependency (GómezMejía et al., 2007), De Massis et al. (2016) instead see such uniqueness of history and intimate understanding of the business as a privileged knowledge base, allowing for a more linear and inimitable innovation process, using family tradition to shape and direct business activities. A dominant identity can therefore be framed as a resource, though which the firms defines is processes and distinguishes from competitors. 
The strength of family identity and the business distinction is brings can be manifest in a number of ways. A heightened concern for reputation and community standing is linked to the defence of family name (Zellweger et al., 2013), often transferring into the minds of society as they consider a trustworthy and transparent organisational form (Craig et al., 2008). Also internally, frequency of communication and common understanding of the nature of business are likely to enhance a shared vision for the organisation and produce better quality decision-making (Sorenson et al., 2009).

Conceptually, there is nothing to stop the extension of benefits from a dominant familial identity to nonfamily employees. For instance, a number of authors suggest that when family members act as stewards of the firm, contagion and mirroring can lead to similarly supportive behaviours in nonfamily employees (Eddleston \& Kellermanns, 2007). However, with practical evidence suggesting that family firms struggle to attract and retain skilled workforce, I follow Deephouse and Jaskiewicz (2013) by questioning whether the strength of family identity reaches as far as nonfamily employees. In particular, I contend that nonfamily employees may struggle to connect with a central family identity when it is built from a history of interaction, understanding and shared experiences.

\section{Nonfamily employees and social identity}

The primacy given to familial concerns and interactions in family firms provides a social group of emotional value and heightened significance. Following social identity theory, individual members of such a group internalise the goals of the collective, so that their own identity becomes defined by their membership (Ashforth \& Mael, 1989; Ashforth \& Schinoff, 2016). In organisational terms, this identification is shaped though the personal bonds of social relationships (Brickson, 2005). The challenge presented in family firms, it that while tight social bonds are possible, even intuitive, among family members, they are less obvious in the case of nonfamily, leading to a difference in status between groups of family employees and nonfamily 
employees in the same firm (Dyer, 2006). At its worst, this pluralism can lead to the unfair treatment of nonfamily employees in favour of the socially privileged family group (Barnett \& Kellermanns, 2006; Verbeke \& Kano, 2012).

Therefore, positing family membership as a valuable and affectual social group, the strength of family ties can limit and even repel extended development through a form of 'amoral familism' (Berrone et al., 2014; Morck \& Yeung, 2004), where the dominant social group encourages a predisposition to distrust the 'other' (Kramer, 1999). This has implications for nonfamily employees as their 'other/outsider' status reduces the influence they have in the firm, constraining their voice as a stakeholder (Björnberg \& Nicholson, 2007).

In spite of such relational complexity, nonfamily employees remain underrepresented in family business research discussions, as we prefer instead to investigate issues of succession, governance, and strategic direction. Those studies that do look to nonfamily employees find an often conflicted character. For instance, Sieger et al. (2011) see nonfamily perceptions of justice, or rather injustice, as causing psychological withdrawal from the organisation, stunting development and contribution to the business. In contrast, Vandekerkhof et al. (2015) see the creation and defence of socioemotional wealth, as opposed to financial wealth, as demanding familial priority and providing justified resistance to the influence of 'others' (Gómez-Mejía et al., 2011). Cabrera-Suárez et al. (2015) share this view and look to familial bonds directed towards socioemotional wealth as leading to dysfunctional behaviours towards any who are not directly associated with it.

Following this line of argument, nonfamily are offered limited buy-in to the more righteous claims of familial and social commitment. Mitchell et al. (2003) have previously noted the cognitive demands this places at the individual level, while Barnett and Kellermanns (2006) look to the potential for HR practices to deal with employee perceptions of justice. However, 
in this article, I look beyond these more structural components and instead focus on the ways in which nonfamily identify with the family firm, if they cannot identify with the family group itself (Carmon et al., 2010). Social identity theory suggests that individuals will instinctively look to rationally categorise themselves, to reduce uncertainty in their social environment (Hogg et al., 2004). This implies that nonfamily will likely perceive the different social groups within the family firm, acknowledging the social distinction of a dominant family group and their own nonfamily group, seeing themselves on the periphery of the organisational identity (Zikic \& Richardson, 2016). In such a way, a social identity perspective would assume that nonfamily form a different identity narrative to that of the dominant identity group (Ashforth et al., 2008). It is to this 'alternative' narrative, which this study pays attention. By understanding the character and content of nonfamily identity, we may be able to better explain the difficulties associated with family firms as employers.

The main contribution of this work is to shift focus from the family unit to the nonfamily employee, whose work life is impacted by a dominant organisational identity. However, I do not look to assume nonfamily as a helpless victim of 'outsider status' and injustice (Van der Hayden et al., 2005). Instead, I explore how identification processes take place for individual nonfamily employees and what meanings are attached to them. The findings challenge the notion of family identity as an omnipresent force in the business (Zellweger et al., 2013) and offer an alternative prospect of a rational and at times self-serving nonfamily employee.

\section{Methodology}

\section{Methods}

In order to apply a social identity perspective to nonfamily in family firms, I follow Ellemers et al. (2002) and look to two separate but crucially related components of social identity. First, I look to the strength of association that nonfamily have with the dominant family firm identity, this not only illuminates the nature of the dominant identity in the firm, but also the connection 
nonfamily feel with this. Second, I look to uncover the content of nonfamily identity as constructed by both nonfamily employees themselves and the controlling family.

A social constructivist approach is adopted to question how nonfamily identity comes to exist and interrelate with organisational identity, as a social production, rooted in discursive and linguistic systems of distinction (Deetz, 2003). This implies that to access the identity structures of nonfamily employees, one must consider the ways in which nonfamily are discussed within the family firm; in relation to how they speak of themselves, but also in how they, are their role, is spoken about by others. In order to achieve this, individual case studies are formed around nonfamily employees. These cases utilise a multiple-informant research design to build a picture of experiential reality, and assess the various linguistic systems called upon to discuss nonfamily employees by assorted organisational members. Critically, this means that each case presented is not only informed by the nonfamily employee, but also by at least one representative from the controlling-family. Cases are presented around the individual nonfamily employee as the unit of analysis, in order to accentuate their identity and experience as an employee.

\section{Data Collection}

Semi-structured interviews were used to gain qualitative data on how nonfamily were perceived in each family firm. This allowed for natural discussion on the role of these employees and the approaches to management taken, data which is then analysed in relation to the guiding theories of the study. Initially, owner-managers of small family firms were approached. The purpose of the study was fully explained, with anonymity and the right to withdraw at any point assured. As part of this process, I requested to speak with employees, in particular, any nonfamily employees. While most organisations approached were willing to allow this, two ownermanagers refused access to the nonfamily employees, for reasons related to work time. Any 
data gained from these owner-mangers were removed from the data set, as without multipleinformant input a comprehensive case could not be built.

For three of the seven firms contributing case data, I was able to speak to all owner-mangers: a father and son; two cousins; and a husband and wife. For the other four firms, only one representative from owner-management was able to contribute. A total of 15 semi-structured interviews, conducted throughout Scotland, are used to provide the data - forming the basis of eight individual nonfamily employee cases, from seven different family firms. Each interview lasted at least 40 minutes in length and was recorded and subsequently transcribed to maintain data validity. Interviews took place on the individual business premises, which also allowed for relevant researcher observations and contextual understanding. Where possible, raw data are presented in tables aligned to the theoretical framework of the study, in order to illuminate analytical interpretation and retain authenticity of findings.

\section{Data Analysis}

Qualitative data are analysed using an adaptation of grounded theory's methodologies (Corbin \& Strauss, 1990). A form of constant-comparative analysis was used to inductively analyse the data. This draws together elements of particular relevance to the research question according to the theoretical framework adopted. Data fragments were first of all categorised within case, and then comparatively assessed both against the frame of social identity theory and the broader themes of the extant literature; for instance, data were separated into those dealing with nonfamily's association with the dominant organisational identity, and those data covering the constructed content of nonfamily identity. From this process, more explanatory themes emerged, both confirming and challenging those in the literature and building a constructed theory on nonfamily social identification (Corley, 2012; Finch, 2002).

Final coding categories are presented in both a visualised and discursive manner, allowing for theoretical and practical implications to emerge. This coding was reviewed by three leading 
professors in the family business and social constructionism fields, and revised based on their interpretation to allow for greater validity and more focused findings. The intention is to reconstruct the social world of the subject (Wiseman, 1974), an approach with inherent limitations. However, the goal of this article helps to provide rich insight and 'thick description' so as to illuminate an as yet under-exposed component of workplace reality (Geertz, 1994).

\section{Case Description}

Due the very complex and subjective nature of social identification, I avoid conflating issues of organisational and other workplace categorisations, such as functionally specific roles (Voss et al., 2006). Therefore, I limit the sample of this study to only those firms owned and managed by a central family unit. These 'clan' family firms are more likely to form around a single organisational identity, a family-business hybrid (Whetten et al. 2014), as opposed to numerous social categorisations; what Albert and Whetten (1985) term holographic, as opposed to ideographic. In practical terms, this means that each employer organisation represented is small in size, with the largest having ten employees, and the smallest five. As previous studies suggest, the uniqueness of family-influenced HRM issues are more likely to arise as the firm is small, prior to growth induced 'professionalization' and the adoption of more formally standardised HRM practices (Kim \& Gao, 2010), therefore this sample of cases allows for issues of organizational identity to be heightened and made more visible to the researcher.

Furthermore, employer organisations represented in the cases are purposefully selected from knowledge-intensive industries (Alvesson, 2004). By focusing on such firms, the study is able to access identity issues in a context sensitive to employee participation and inclusion, where HRM behaviours can have great impact on the performance of the organisation (Chuang et al., 2016). Table 1 presents each of the cases, and indicates the individuals contributing data to the study, along with details of the organisational context. 


\section{Analysis and interpretation}

\section{Nonfamily in the organisational context}

Table 1 describes the nature of each nonfamily employee in their respective family business. It shows a varied length of employment and industry across the eight cases. These initial descriptions also show that the nonfamily employees fill a variety of roles in their organisations. From administration, through sales, and then John who holds the title of co-director (with the other co-directors all controlling-family members). While this may suggest that nonfamily are able to develop into all levels of family firm management and operation, these roles are titlebased. Investigation into the social identity of these individuals produces a far more nuanced picture.

Table 1: Nonfamily in the organisational context

\begin{tabular}{|c|c|c|c|c|c|c|c|}
\hline Respondent & Industry & Position & $\begin{array}{c}\text { Length of } \\
\text { employment }\end{array}$ & $\begin{array}{l}\text { Age of } \\
\text { firm }\end{array}$ & $\begin{array}{l}\text { Size of } \\
\text { firm }\end{array}$ & $\begin{array}{l}\text { Family in the } \\
\text { firm }\end{array}$ & $\begin{array}{c}\text { Family } \\
\text { generation of } \\
\text { ownership }\end{array}$ \\
\hline John & $\begin{array}{c}\text { Events } \\
\text { management }\end{array}$ & Co-director & 15 years & 17 & 5 & $\begin{array}{c}\text { Sister }{ }^{1} \text { and } \\
\text { brother - } \\
\text { director/owner; } \\
\text { uncle - company } \\
\text { secretary; sister } \\
\text { - part-time } \\
\text { employee }\end{array}$ & $2^{\text {nd }}$ \\
\hline Michael & $\begin{array}{c}\text { Financial } \\
\text { services }\end{array}$ & $\begin{array}{c}\text { Client } \\
\text { advisor/sales }\end{array}$ & 2 years & 6 & 4 & $\begin{array}{c}\text { Step-son }{ }^{1} \text { and } \\
\text { step-mother - } \\
\text { director/owner; } \\
\text { father - external } \\
\text { advisor (not } \\
\text { employed) }\end{array}$ & $1^{\text {st }}$ \\
\hline Polly Jane & Estate agents & Administration & 3 years & 3 & 7 & $\begin{array}{l}\text { Husband }^{1} \text { and } \\
\text { wife - } \\
\text { director/owner; } \\
\text { daughter - part- } \\
\text { time employee }\end{array}$ & $1^{\text {st }}$ \\
\hline Marie & Estate agents & Administration & 11 years & 37 & 8 & $\begin{array}{l}\text { two brothers }{ }^{1}- \\
\text { director/owner; } \\
\text { son - full-time } \\
\text { employee }\end{array}$ & $2^{\text {nd }}$ \\
\hline Debbie & Education & Teacher & 3 years & 15 & 5 & $\begin{array}{l}\text { Husband and } \\
\text { wife }^{2}- \\
\text { director/owner; } \\
\text { daughter - } \\
\text { casual employee }\end{array}$ & $1^{\text {st }}$ \\
\hline Jennifer & $\begin{array}{l}\text { Insurance } \\
\text { broker }\end{array}$ & Administration & 3 years & 79 & 10 & $\begin{array}{l}\text { two cousins } \\
\quad(\text { male })- \\
\text { director/owner; } \\
\text { daughter - full- } \\
\text { time employee }\end{array}$ & $3^{\text {rd }}$ \\
\hline
\end{tabular}




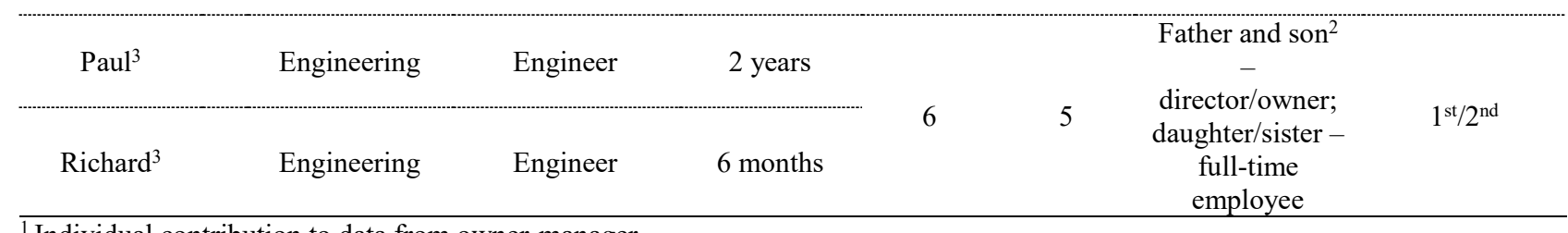

${ }^{1}$ Individual contribution to data from owner-manager

${ }^{2}$ Both contribute to data from owner-management

${ }^{3}$ Nonfamily participants employed by the same firm

Following generational trends of family firm survival (Stamm \& Lubinski, 2011), three of the respondents work in first generation family businesses, two in second generation, and one (Jennifer) in the most established organisation represented: a third generation insurance broker founded by the owner cousins' grandfather, and passed through one of the cousin's fathers. Cross-generational involvement within each firm is mostly in the form of offspring taking on an employee role, John works in an organisation where the owner's uncle acts as company secretary, and Richard and Paul's employer is currently in the succession process between father and son, with both currently working in the organisation (though the son has formal control).

Organisational forms vary in the sample, from husband and wife directorship to cousin consortium. Michael perhaps needs to contend with the least typical scenario, where firm ownership is shared between a son and his step-mother. The range of family control forms represented here is testament to the heterogeneity of family businesses in general (Westhead \& Howorth, 2007), an important aspect to shed light on the strength of family presence each respondent faces.

\section{Association with family firm identity}

Following social identity theory, the first aspect I consider is the extent to which nonfamily perceive themselves as psychologically interwoven with the organisational identity of the family firm (Ashforth \& Mael, 1989). When a particular social identity is situationally relevant and valued, such as the dominant family group in a family firm, individuals may seek to selfcategorise and align with that identity (Hogg \& Terry, 2000). A process of depersonalisation 
can occur, where the individual internalises 'target' identity prototypes of attitude and behaviour in order to be accepted by the group (Nkomo \& Stewart, 2006). For family-related employees this process can be relatively intuitive as they can tap into shared histories, connected goals, and known intentions. However, it presents a problem for the nonfamily employee who may be unable to 'depersonalise' and assimilate with close family identity due to their 'outsider' status.

While each organisational context differs across a variety of factors, what becomes clear from Table 2 is that association with the family aspects of the firm is characterised, to some extent, with a theme of detachment. The central family are typically classed as 'the decision-makers', the ones who are 'in control' of what goes on. If we follow the principles of social identity construction, building the family unit as an 'other' controlling category allows nonfamily to create distinction (Sveningsson \& Alvesson, 2003). Withdrawing from the perceived collective group of 'they' - referring to 'the family' - demonstrates to some extent that nonfamily acknowledge a collective identity in the organisation, but that it is one in which they do not play a part (Turner and Reynolds, 2004). In this respect, nonfamily seem to maintain an individual standing and accept that a familial collective deal with organisational problems in their own manner.

From this detachment, it appears that nonfamily make sense of their role by contrasting with family members who demonstrate better fit with the organisation, to use Dutton et al.'s (1994) terminology. The approaches of Michael and Richard point to a social awkwardness in nonfamily, particularly when it comes to disagreements within the family group. The "keep your head down and don't get involved" (Richard) attitude suggests an unwillingness to infiltrate what they see as a personal and even domestic situation. However, some respondents also point to feeling closer to the organisational identity, due to the presence of family. For instance, Marie and Polly Jane refer to the organisation as being "close knit" and feeling "part 
and parcel of how things are done", while Debbie highlights how the length of tenure she has allows her to feel "one of them" (although she has only been with the organisation three years). What's interesting is that these reflections on the surface appear to contradict other respondents who point to detachment from the organisational identity; however, on closer inspection, they tend to focus on how the individual is made to feel in the organisation, as opposed to a definite identification with the collective group. This is highlighted again by the comments of Debbie, who claims to feel part of the collective group, but then points to a structural exclusion when it comes to meetings. This paradox is perhaps explained when we consider the second theme of psychological ownership in nonfamily employees.

There is a sense of pride in the respondents, that they perform tasks with affective impact on organisational outcomes and a heightened responsibility to support the controlling family, endorsing Ramos et al.'s (2014) finding on a role and task focus in nonfamily psychology. However, many of the respondents suggest that such impact is more related to the small size of the business rather than any familial identification. The emotional attitude of "get[ing] on with [the job]" (Richard) and "just work[ing] away" (Marie) creates a distance from the goals of the organisation as a whole. This pulls into question how much nonfamily associate with the more macro notions of socioemotional wealth creation attributed to family firms (Gómez-Mejía et al., 2007). Where values of socioemotional wealth hold strong currency, anyone not directly contributing to such values is likely pushed to the fringes of the social group (Vandekerkhof et $a l ., 2015)$. Ownership of role as opposed to organisation may be a reaction to this resistance, as the strongest emotional attachment nonfamily can gain from their fringe position.

The themes of detachment from a remote organisational identity also echo those of Lubatkin et al.'s (2007) and Van der Hayden et al. (2005) when they speak of justice perception and fair practice. However, instead of focusing on subservience to the dominance of family (Barnett \& Kellermanns, 2006) and the potential for deviant behavioural implications (Marler \& Stanley, 
2018), the findings here suggest a level of workplace agency in nonfamily, where pride of task performance allows individuals to feel a contribution to the group. Theories on agency have previously been questioned in the family business context, as assumptions on goal alignment and closely held relationships dominate (Westhead \& Howorth, 2006). However, in the specific context of nonfamily, these assumptions do not hold and agency theory may indeed provide some insight into the behaviours of this isolated identity. For instance, as nonfamily are detached and therefore not led by family identity, family business managers may look to develop nonfamily performance via agency-control mechanisms: for example, performancerelated pay, quantifiable objectives, and directional leadership (Schulze et al., 2003; Sieger et al., 2011). Conceptualising nonfamily employees as a more withdrawn agency-based character in the web of family business relationships supports Chua et al. (2003) by challenging a previously held assumption that such traditional forms of work relationship are less problematic in family businesses (Fama \& Jensen, 1983). Instead, it can be suggested that the difficulties in connecting with organisational identity in fact heighten associated agency 'problems' with nonfamily, as it forces them to adopt an independent task-orientation over an interdependent reciprocal exchange (Flynn, 2005).

Table 2: Association with organisational identity

\begin{tabular}{lll} 
Respondent & \multicolumn{1}{c}{ The detached 'I' from 'they' } & \multicolumn{1}{c}{ Ownership of role } \\
\hline John & $\begin{array}{l}\text { 'the family are the decision makers... I mean [the] } \\
\text { family comes first, in terms of the how the family } \\
\text { and the business go forward' }\end{array}$ & $\begin{array}{l}\text { 'I've been here an awful long time, I have the } \\
\text { financial information, I decide, or take a view } \\
\text { when some of the bills are paid' }\end{array}$ \\
\hline Michael & $\begin{array}{l}\text { 'They're the ones that actually have overall control } \\
\text { of the situation, so they have the final say.... that's } \\
\text { personal, I don't dare get involved in that' }\end{array}$ & $\begin{array}{l}\text { 'I'm pretty much on my own, you know, I'm self- } \\
\text { sufficient, I don't have to rely on any business } \\
\text { coming from them' }\end{array}$ \\
\hline Polly Jane & $\begin{array}{l}\text { 'From a personal satisfaction point of view that's, } \\
\text { you feel that you're part and parcel of how things } \\
\text { are done' }\end{array}$ & $\begin{array}{l}\text { 'It's probably (task) ownership as opposed to the, } \\
\text { 'I've got money shares', or whatever... You can } \\
\text { have a lot more input on direction, or just a } \\
\text { change in how we do things' }\end{array}$ \\
\hline Marie & $\begin{array}{l}\text { 'I thinks it's quite a close knit, quite a cosy family } \\
\text { kind of, you know we go out for quite a lot of } \\
\text { meals and things.' }\end{array}$ & $\begin{array}{l}\text { 'We try and help as much as we can with some } \\
\text { people (customers) they just want to speak to him } \\
\text { (family owner)'. }\end{array}$ \\
& $\begin{array}{l}\text { 'We're quite happy, just happy being secretaries } \\
\text { and just work away'. }\end{array}$
\end{tabular}




\begin{tabular}{|c|c|c|}
\hline Debbie & $\begin{array}{l}\text { 'There [is] the family and there was everybody } \\
\text { else... I've been here for quite a long time... I } \\
\text { actually feel like I'm 'one of them,' } \\
\text { 'We don't do meetings particularly right, because } \\
\text { they just do it round the breakfast table.' }\end{array}$ & $\begin{array}{l}\text { 'I think I perhaps, I feel a bit more guilty [sic] } \\
\text { about things, because it's a family business, so } \\
\text { guilty about being away.' }\end{array}$ \\
\hline Jennifer & $\begin{array}{l}\text { 'The family side of things comes across, and it's } \\
\text { very very important.' } \\
\text { 'They will react to anything... [but] everything is } \\
\text { ultimately down to them, any issues.' }\end{array}$ & $\begin{array}{l}\text { 'It's still run by members of the original family, I } \\
\text { think everyone takes a lot of pride in that.' } \\
\text { 'You know the impact that [work] has on } \\
\text { everyone that's here' }\end{array}$ \\
\hline Paul & $\begin{array}{l}\text { 'Jon is the boss, although Rich asked for something } \\
\text { today to get done, it gets done, even over Jon, just } \\
\text { because he's his father... sometimes there's a } \\
\text { personal disagreement... you just feel as if you } \\
\text { shouldn't be in the room at that point.' }\end{array}$ & $\begin{array}{l}\text { 'You need to think about your role in the } \\
\text { business' } \\
\text { '[You have] a higher amount of personal } \\
\text { responsibility' }\end{array}$ \\
\hline Richard & $\begin{array}{l}\text { 'You definitely feel as if you're consulted, certainly } \\
\text { on where your own area of the business is going' } \\
\text { '[With family disagreements] just sort of, be quite, } \\
\text { keep your head down, don't get involved.' }\end{array}$ & $\begin{array}{l}\text { 'I was sort of brought in, certainly at this stage in } \\
\text { a defined role, to do a defined job within the } \\
\text { company' } \\
\text { 'In here, you get on with it' }\end{array}$ \\
\hline
\end{tabular}

\section{Content of nonfamily identity}

The second aspect of social identity theory considers how nonfamily identity content is constructed (Ashforth \& Schinoff, 2016). Following this, we assume people derive selfconception from the role they play in interactions and the meaning attached to this (Ibarra, 1999). Accordingly, Watson (2008) sees identity construction as a mutual struggle between how individuals conceive of themselves and 'coming to terms with' the identities related to them by others. Sveningsson and Alvesson (2003) point to this as a continual cycle of revision and reformulation in the pursuit of coherence and distinction. How the nonfamily employee is constructed in the narrative of family business, by both the employee and the central family unit, has implications for behaviours and attitudes.

From Table 3, the first aspect to draw attention to is the overriding notion from both perspectives, though primarily the controlling family, that nonfamily act as an auxiliary to the main core of the workforce ${ }^{1}$. For instance, the phrase "blood is thicker than water" (Maire)

\footnotetext{
${ }^{1}$ Borrowed from Plato's auxiliary class of rational acting individuals subordinate to some form of greater reasoning (Schmid, 2015).
} 
appears often when the controlling family discuss nonfamily. While this may be a whimsical cliché, it does appear to carry great weight, as Maire's employer defends that family owners are "entitled" to be "unfair" in their HRM practices (Bello-Pintado \& Garcés-Galdeano, 2017). Debbie's and John's employers echo this sentiment by focusing on the lack of career development offered to nonfamily, implying that, at times, familial retrenchment may occur (Tsao et al., 2016). Polly Jane's employer adds another dimension by describing family as "necessary", suggesting that nonfamily is less necessary and indeed something that requires surveillance, again highlighting the role of agency-control mechanisms. Though nonfamily are not as blunt in their language, on the whole they do concede a lack of workplace development. Michael states this most clearly, explaining the only viable way to "move forward" is to part ways with his family business employers.

However, Jennifer, Paul and Richard's situations are particular interesting in this regard. Jennifer's family employers reiterate the lack of progression opportunity for nonfamily, yet they leave the door agar for something they consider "excellent". And Jennifer herself suggests that the opportunity of flexibility and pride in the impact of her work gives her a sense of achievement. Paul and Richard's situation takes this a stage further, with the family owners referring to their nonfamily employees as "likeminded" "professionals" with "similar histories". Paul sees this akin to being taking into the family, and a quote from the head of the family business explains the implications of this:

"The biggest fear I've got is that for whatever reason I'll not be able to pay my mortgage and I'll lose my house and when you're in a family business, as we are just now, that's growing, having gone from one individual to five going on seven in cases, now, I've now got to think of five other mortgages [including nonfamily] before we think of our own". (Controlling family owner - Paul) 
Although this demonstrates the added pressure of involving nonfamily, it also shows a regard for nonfamily status which is distant to the auxiliary identity discussed above, moving towards a more integrated nonfamily identity as a deviant case to the more common auxiliary.

A final theme covers what nonfamily perceive as benefits received by working in a family firm. For instance, John and Richard highlight the flexibility benefits gained in a "family environment", with Richard detailing that this is particularly beneficial for his own young family. It should be noted here that Richard has only been with his organisation six months and even at this early stage finds the firm sensitive to work-family conflict (Davis \& Kalleberg, 2006). Marie's family employer acknowledges this flexibility, claiming a level of generosity to nonfamily. Receiving such benefits is often brought up in the context of restricted development opportunity. Additionally, Michael, Marie and Paul portray the contribution they make to business. By helping the company and "assisting through the heavens" (Paul) the respondents stress that they deserve and benefits received as some kind of 'balance'. This is a view sparsely noted by the controlling family, aside from the case of Paul and Richard's controlling family, who note professional contribution "when required". It would appear that nonfamily in this regard suggest a greater work effort is required as a condition of the flexible benefits received (Mankelow, 2008).

Table 3: Content of nonfamily identity

\begin{tabular}{|c|c|c|}
\hline Respondent & $\begin{array}{c}\text { A beneficiary } \\
\text { (Comments from nonfamily employee) }\end{array}$ & $\begin{array}{c}\text { An auxiliary } \\
\text { (Comments from controlling family) }\end{array}$ \\
\hline John & $\begin{array}{l}\text { 'It allowed me a lot of flexibility' } \\
\text { 'You have to go in, I think with your eyes open... } \\
\text { they (family) might not match your own aspirations.' }\end{array}$ & $\begin{array}{l}\text { 'I don't see it as my job to drive him forward ... He } \\
\text { doesn't have a career path that he's going to move } \\
\text { down anyway... I think the family will probably go } \\
\text { the extra mile when necessary... blood is stronger } \\
\text { than water, and it is' }\end{array}$ \\
\hline \multirow[t]{2}{*}{ Michael } & $\begin{array}{l}\text { 'Well I'm helping (the family business) out, I'm } \\
\text { earning off him. But the more I do the more he gets.' }\end{array}$ & $\begin{array}{l}\text { 'We're not cliquey or anything... they work under } \\
\text { my umbrella and I'm responsible for them.' }\end{array}$ \\
\hline & $\begin{array}{l}\text { 'The only way for me to move forward would be to } \\
\text { leave the company.' }\end{array}$ & $\begin{array}{l}\text { 'I wouldn't want a business partner. No, I just want } \\
\text { it to be me and Carole (step-mother) with a share in } \\
\text { the business.' }\end{array}$ \\
\hline
\end{tabular}




\begin{tabular}{|c|c|c|}
\hline Polly Jane & $\begin{array}{l}\text { 'If I was wanting work done by one of our } \\
\text { contractors then I would get priority in my stuff } \\
\text { getting carried out on a personal basis' } \\
\text { 'If they were going a route that I really thought, (is) } \\
\text { wrong for me. Then you're on a hiding to nothing } \\
\text { really, aren't you.' }\end{array}$ & $\begin{array}{l}\text { 'The family is so necessary to make decisions. } \\
\text { Because, you know it could be out of hours it could } \\
\text { be, if the funds aren't available we all pull } \\
\text { together.' } \\
\text { '[Nonfamily] talk amongst themselves all the time. } \\
\text { They don't know I'm aware of it. I wouldn't be a } \\
\text { very good businesswoman if I didn't [sic].' }\end{array}$ \\
\hline Marie & $\begin{array}{l}\text { 'Keith (family owner) has helped me a lot over the } \\
\text { years and I help his company as well, so it's well } \\
\text { balanced' }\end{array}$ & $\begin{array}{l}\text { 'We're very flexible, we're very generous as well.' } \\
\text { 'Blood is thicker than, than water, effectively... } \\
\text { things aren't fair and the company owners are } \\
\text { entitled to do what they want at the end of the day.' }\end{array}$ \\
\hline Debbie & $\begin{array}{l}\text { 'It's actually very secure. You know that it will get } \\
\text { sorted out if there's a problem... I mean in terms of } \\
\text { my own job security.' }\end{array}$ & $\begin{array}{l}\text { 'If you're thinking about career progression for } \\
\text { people, we haven't really got that much, because, } \\
\text { we don't want to be a multi-national company.' }\end{array}$ \\
\hline Jennifer & $\begin{array}{l}\text { 'They are so family orientated, even me with my own } \\
\text { family, well they're absolutely, they're great to work } \\
\text { for.' } \\
\text { 'The flexibility and just opportunity to take pride in } \\
\text { your work and see the impact in what you're actually } \\
\text { achieving.' }\end{array}$ & $\begin{array}{l}\text { 'There is limited progression. We wouldn't be } \\
\text { opposed to, bringing [nonfamily] on board. But it } \\
\text { would need to be something major, sea change as it } \\
\text { were... They have to bring something very different } \\
\text { or maybe excellent.' }\end{array}$ \\
\hline Paul & $\begin{array}{l}\text { '[Family] a bit more relaxed, as if you've been taken } \\
\text { into part of their family, whilst assisting through the } \\
\text { heavens.' }\end{array}$ & $\begin{array}{l}\text { '[We have] others (nonfamily) that get called upon } \\
\text { as and when required.' }\end{array}$ \\
\hline Richard & $\begin{array}{l}\text { 'Their more parental, because it is a family } \\
\text { environment, they're a bit more sympathetic to, 'my } \\
\text { daughter's not well', or something like that, I find } \\
\text { that is a benefit.' }\end{array}$ & $\begin{array}{l}\text { likeminded individuals. Similar backgrounds, } \\
\text { similar histories.' } \\
\text { 'The two guys who are outwith the family are } \\
\text { professional in the engineering sense.' }\end{array}$ \\
\hline
\end{tabular}

Based on these findings, the content of nonfamily identity is structured at some level on whether these employees are considered auxiliary to, or more integrated in the organisation. Accentuating benefits gained is often used to reconcile the auxiliary nature of the role. While the mix of these elements will be unique to each family business, and indeed the individual themselves, the ways in which nonfamily identity is constructed and interacts with family firm organisational identity has clear implications for staff well-being and employee voice $(\mathrm{Hu} \&$ Jiang, 2016; Newman et al., 2016).

\section{Discussion and implications}

This work addresses calls from Harris et al. (2004) for more detailed case understandings of HRM in family firms. Examining nonfamily employees from the perspective of organisational identity illustrates some of the more nuanced consequences of family influence. Nonfamily demonstrate their relationship with the family business by identifying as a self-interested 
auxiliary to those who are integrated in the more dominant family identity. In this sense, the most salient identity draw for nonfamily is the draw to develop their own personal identity as a primary consideration. Nonfamily are found to move through a process of self-definition based on agency assumptions, where inclusion into the principal organisational identity would be illegitimate. An attachment to their role and function is performative in the sense that it allows them to act according to more traditional employee identity beliefs, motivated by conventional compensations and workplace benefits. Indeed, the lure of anything greater in the familyinfluenced organisational identity is often deflected by a structured and unassailable barrier of kinship. The implications of this barrier, whether intentional or not, is that family businesses cannot rely of the notion of socioemotional wealth to generate commitment from nonfamily employees. If this powerful vision exists in the make-up of family firm identity, it sits behind a fortified wall with little meaning or reach to those nonfamily on the other side.

However, to reduce the nonfamily relationship to a principal-agent basis would be to oversimplify. Unassailable connections to organisational identity can lead negative perceptions of organisational justice, lack of buy-in to vision, and uncooperative behaviours (Stets \& Burke, 2000). The behavioural implications are such that nonfamily cannot be relied upon to display the same organisational citizenship fostered by family identity (Marler \& Stanley, 2018), paradoxically, reducing the effects of family influence on the business. In this sense, my findings support Schulze et al.'s (2003) view that agency costs are indeed heightened in the family-influenced business, requiring careful management of incentives and motivations.

All eight cases highlight family/nonfamily categorisation of identity, overpowering all other forms of social identity (professional, gender, identities of place, etc.). In these instances, nonfamily present as a minimal group against the valid and valued family. They appear to concede superiority to family, and develop an alternative dimension of identity in order to derive a positive character from the benefits taken. According to Ellemers et al. (2002), these 
affirming responses are born from the uncertainty of group membership, and are therefore a direct reaction to powerlessness in identifying with the broader organisation. Such comparisons and distinctions can be self-fulfilling and reinforce the psychological distance between the two groups. As an extreme, we can view nonfamily as alienated by a lack of consideration from the salient identity group, rendering them unable to internalise the goals of the group (Hogg \& Reid, 2006), potentially damaging self-esteem and limiting citizenship behaviours (Riketta, 2005).

Social identity theory purposefully does not equate such in-group/out-group bias with social hostility (Turner \& Reynolds, 2004). The findings here support this. There is no resentment noted in the construction of nonfamily, more a self-serving acceptance of status. Nor do the findings suggest any suspicion or fear in the direction of family towards nonfamily (Poza et al., 2004). Instead, there appears to be an occasionally unsympathetic indifference to nonfamily. This shows a rather different implication of family-based organisational identity to the sociallyemotional shared vision we are led to expect (Sorenson et al., 2009). Instead, alternative identity narratives are found to co-exist, which can each contribute to the goals of the firm (Vardaman et al., 2018), but have individually specific behavioural implications for how individuals deal with their various statuses in the firm.

\section{Conclusions}

The main theoretical contribution of this work is to answer urgent calls for greater attention to nonfamily voice in family business (Xi et al., 2014). However, I also look to address Fletcher et al.'s (2016) worry on the regrettable lack of qualitative methodologies in developing family firm understanding. Attention to nonfamily employees is essential for sustainability in family firms where, typically, there can be difficulties in attracting new talent (Botero, 2014). The findings also extend our understanding of socioemotional wealth preservation (Berrone et al., 2014). They challenge the idea that a desire for socioemotional wealth will lead family firms to 
a greater concern for employee satisfaction, and instead support Vandekerkhof et al. (2015) by pointing to an exclusivity which alienates nonfamily. Family business management should seek to understand the various motivations and incentives which drive nonfamily. I have found that these vary from flexibility, to emotional needs of contribution, with no specific economic drive; providing qualitative evidence of Sánchez-Marín et al.'s (2017) calls for more contextual understanding of HR practices.

From a managerial perspective, the more family firms consider their unique context, the greater chance they have of building systems to avoid undesirable consequences, such as high turnover or unsatisfied staff (Vardaman et al., 2018). As family firm managers focus on building unique resources from their idiosyncratic ecosystem (Habbershon, 2006), they must also understand the 'darker' consequences of a tight and exclusive organisational identity (Linstead et al., 2014). Thus, it could be argued that this contributes to a more critical turn in family business knowledge (Neckebrouck et al., 2018), where the more righteous elements of family influence can lead to the isolation of those not as closely affiliated. From the findings of this study, there are implications for how family firm managers should approach such 'alternative' identities. For instance, it seems that nonfamily are self-serving in their approach to the firm, therefore more typically agency-based managerial relationships may be appropriate for nonfamily, counter to suggestions that shared values lessen agency problems in family firms (Schulze et al., 2003). Also, while there is general acceptance that career progression will be limited for nonfamily, other benefits of working in the firm can be offered, such as flexibility, generosity of time, and sensitivity to home-life pressures (Davis \& Kalleberg, 2006).

\section{Limitations and future research}

Clearly, a work such as this has many limitations. The small sample size associated with indepth qualitative analysis renders any generalisability impossible. It should also be noted that data are taken from small family firms within Scotland. While there is little to suggest that 
issues of identity will differ in other countries, future work could focus on an international comparison to investigate the role of national culture. Furthermore, I have not considered the implications for workplace behaviours here. Future works may also consider how the behaviours of family and nonfamily employees differ, aligned to organisational identity. Another potential implication of nonfamily identity is longevity. While turnover of nonfamily is likely higher than family, it would be interesting to consider how the identity of nonfamily employees changes over time with the organisation. There is clearly a lot of scope to develop our understanding of family business as a workplace.

\section{References}

Albert, S., \& Whetten, D.A. (1985). Organizational identity. In: L. L. Cummings, \& B. M. Straw (eds.), Research in Organizational Behavior. Greenwich, CA: JAI, 263-295.

Alvesson, M. (2004). Knowledge work and knowledge-intensive firms. Oxford University Press: Oxford.

Ashforth, B.E., \& Mael, F. (1989). Social identity theory and the organization. Academy of Management Review, 14(1), 20-39.

Ashforth, B.E., \& Schinoff, B.S. (2016). Identity Under Construction: How Individuals Come to Define Themselves in Organizations. Annual Review of Organizational Psychology and Organizational Behavior, 3, 111-137.

Ashforth, B.E., Harrison, S.H., \& Corley, K.G. (2008). Identification in organizations: An examination of four fundamental questions. Journal of Management, 34(3), 325-374.

Barnett, T., \& Kellermanns, F.W. (2006). Are we family and are we treated as family? Nonfamily employees' perceptions of justice in the family firm. Entrepreneurship Theory and Practice, 30(6), 837-854. 
Barnett, T., Eddleston, K., \& Kellermanns, F.W. (2009). Business owners' role salience, career satisfiers, and performance-related outcomes in family versus non-family firms. Family Business Review, 22(1), 39-52.

Bello-Pintado, A., \& Garcés-Galdeano, L. (2017). Bundles of HRM practices in family and non-family firms: the impact on enhancing performance. International Journal of Human Resource Management, 1-22.

Berrone, P., Cruz, C., \& Gomez-Mejia, L.R. (2014). Family-controlled firms and stakeholder management: a socioemotional wealth preservation perspective. In: L. Melin; M. Nordqvist; P. Sharma (eds.). The SAGE Handbook of Family Business. London: SAGE Publications Ltd. Pages: 179-196.

Björnberg, Å., \& Nicholson, N. (2007). The family climate scales-Development of a new measure for use in family business research. Family Business Review, 20(3), 229-246.

Bjuggren, C.M., Johansson, D., \& Sjögren, H. (2011). A note on employment and gross domestic product in Swedish family-owned businesses: A descriptive analysis. Family Business Review, 24(4), 362-371.

Botero, I.C. (2014). Effects of communicating family ownership and organisational size on an applicant's attraction to a firm: An empirical examination in the USA and China. Journal of Family Business Strategy, 5(2), 184-196.

Brickson, S.L. (2005). Organizational identity orientation: Forging a link between organizational identity and organizations' relations with stakeholders. Administrative Science Quarterly, 50(4), 576-609.

Briner, R.B., Denyer, D., \& Rousseau, D.M. (2009). Evidence-based management: concept cleanup time?. Academy of Management Perspectives, 23(4), 19-32. 
Cabrera-Suárez, M.K., Déniz- Déniz, M.C., \& Martín-Santana, J.D. (2015). Family social capital, trust within the TMT, and the establishment of corporate goals related to nonfamily stakeholders. Family Business Review, 28(2), 145-162.

Carmon, A.F., Miller, A.N., Raile, A.N., \& Roers, M.M. (2010). Fusing family and firm: Employee perceptions of perceived homophily, organizational justice, organizational identification, and organizational commitment in family businesses. Journal of Family Business Strategy, 1(4), 210-223.

Chrisman, J.J., Chua, J.H., \& Sharma, P. (2005). Trends and directions in the development of a strategic management theory of the family firm. Entrepreneurship Theory and Practice, 29(5), 555-576.

Chua, J.H., Chrisman, J.J., \& Sharma, P. (2003). Succession and nonsuccession concerns of family firms and agency relationship with nonfamily managers. Family Business Review, 16(2), 89-107.

Chuang, C.H., Jackson, S.E., \& Jiang, Y. (2016). Can knowledge-intensive teamwork be managed? Examining the roles of HRM systems, leadership, and tacit knowledge. Journal of Management, 42(2), 524-554.

Corbin, J.M., \& Strauss, A. (1990). Grounded theory research: Procedures, canons, and evaluative criteria. Qualitative Sociology, 13(1), 3-21.

Corley, K. (2012). Publishing in AMJ—Part 7: What's Different about Qualitative Research?. Academy of Management Journal, 55(3), 509-513.

Craig, J., Dibbrell, C., \& Davis, P.S. (2008). Leveraging family-based brand identity to enhance firm competitiveness and performance in family businesses. Journal of Small Business Management, 46(3), 351-371.

Davis, A.E., \& Kalleberg, A.L. (2006). Family-friendly organizations? Work and family programs in the 1990s. Work and Occupations, 33(2), 191-223. 
de Kok, J.M., Uhlaner, L.M., \& Thurik, A.R. (2006). Professional HRM Practices in Family Owned-Managed Enterprises. Journal of Small Business Management, 44(3), 441-460.

De Massis, A., Frattini, F., Kotlar, J., Petruzzelli, A.M., \& Wright, M. (2016). Innovation through tradition: lessons from innovative family businesses and directions for future research. Academy of Management Perspectives, 30(1), 93-116.

Deephouse, D.L., \& Jaskiewicz, P. (2013). Do family firms have better reputations than nonfamily firms? An integration of socioemotional wealth and social identity theories. Journal of Management Studies, 50(3), 337-360.

Deetz, S. (2003). Disciplinary power, conflict suppression and human resources management. In: M. Alvesson \& H. Willmott (eds.) Studying Management Critically, London: SAGE Publications Ltd. 23-45.

Department for Business Innovation \& Skills (2015) Small business survey 2014: SME $\begin{array}{lllll}\text { employers. } & \text { [online]. } & \text { Retrieved } & \text { (2018, }\end{array}$ https://www.gov.uk/government/uploads/system/uploads/attachment_data/file/414963/bis15-151-small-business-survey-2014-sme-employers_v1.pdf

Dutton, J.E., Dukerich, J.M., Harquail, C.V. (1994). Organizational images and member identification. Administrative Science Quarterly, 39(2), 239-263.

Dyer, W.G. (2006). Examining the "family effect" on firm performance. Family Business Review, 19(4), 253-273.

Dyer, W.G., \& Whetten, D.A. (2006). Family firms and social responsibility: Preliminary evidence from the S\&P 500. Entrepreneurship Theory and Practice, 30(6), 785-802.

Eddleston, K.A., \& Kellermanns, F.W. (2007). Destructive and productive family relationships: A stewardship theory perspective. Journal of Business Venturing, 22(4), 545-565.

Ellemers, N., Spears, R., \& Doosje, B. (2002). Self and social identity. Annual Review of Psychology, 53(1), 161-186. 
European Commission (2009) Overview of family-business-relevant issues: research, networks, policy measures and existing studies. Final report of the expert group [online]. Retrieved March 6, 2018, from http://ec.europa.eu/DocsRoom/documents/10388

Fama, E.F., \& Jensen, M.C. (1983). Agency problems and residual claims. Journal of law \& Economics, 26(2), 327-349.

Fang, H., Memili, E., Chrisman, J.J., \& Penney, C. (2017). Industry and information asymmetry: the case of the employment of non-family managers in small and medium-sized family firms. Journal of Small Business Management, 55(4), 632-648.

Finch, J.H. (2002). The role of grounded theory in developing economic theory. Journal of Economic Methodology, 9(2), 213-234.

Fletcher, D., De Massis, A., \& Nordqvist, M. (2016). Qualitative research practices and family business scholarship: a review and future research agenda. Journal of Family Business Strategy, 7(1), 8-25.

Flynn, F.J. (2005). Identity orientations and forms of social exchange in organizations. Academy of Management Review, 30(4), 737-750.

Gagné, M., Sharma, P., \& De Massis, A. (2014). The study of organizational behavior in family business. European Journal of Work and Organizational Psychology, 23(5), 643-656.

Geertz, C. (1994). Thick description: Toward an interpretive theory of culture. In: M. Martin, L.C. McIntyre (eds.) Readings in the Philosophy of Social Science, Boston: MIT Press, 213231.

Gilding, M., Gregory, S., \& Cosson, B. (2015). Motives and outcomes in family business succession planning. Entrepreneurship Theory and Practice, 39(2), 299-312.

Gómez-Mejía, L.R., Cruz, C., Berrone, P., \& De Castro, J. (2011). The bind that ties: socioemotional wealth preservation in family firms. Academy of Management Annals, 5(1), 653-707. 
Gómez-Mejía, L.R., Haynes, K.T., Núñez-Nickel, M., Jacobson, K.J., \& Moyano-Fuentes, J. (2007). Socioemotional wealth and business risks in family-controlled firms: Evidence from Spanish olive oil mills. Administrative Science Quarterly, 52(1), 106-137.

Habbershon, T.G. (2006). Commentary: A framework for managing the familiness and agency advantages in family firms. Entrepreneurship Theory and Practice, 30(6), 879-886.

Harris, R.I., Reid, R.S., \& McAdam, R. (2004). Consultation and communication in family businesses in Great Britain. International Journal of Human Resource Management, 15(8), $1424-1444$.

Hogg, M. A., \& Reid, S. A. (2006). Social identity, self-categorization, and the communication of group norms. Communication theory, 16(1), 7-30.

Hogg, M.A., \& Terry, D.I. (2000). Social identity and self-categorization processes in organizational contexts. Academy of Management Review, 25(1), 121-140.

Hogg, M.A., Abrams, D., Otten, S., \& Hinkle, S. (2004). The social identity perspective: Intergroup relations, self-conception, and small groups. Small Group Research, 35(3), 246276.

Hu, X., \& Jiang, Z. (2016). Employee-oriented HRM and voice behavior: a moderated mediation model of moral identity and trust in management. International Journal of Human Resource Management, doi./10.1080/09585192.2016.1255986

Ibarra, H. (1999). Provisional selves: Experimenting with image and identity in professional adaptation. Administrative Science Quarterly, 44(4), 764-791.

IFB Research Foundation (2016) The state of the nation: the UK family business sector 2016/17. [online]. Retrieved March 6, 2018, from http://www.ifb.org.uk/media/3090/ifbrfsector-report-2016-17-final-web-version.pdf 
Jaskiewicz, P., Uhlenbruck, K., Balkin, D.B., \& Reay, T. (2013). Is nepotism good or bad? Types of nepotism and implications for knowledge management. Family Business Review, 26(2), 121-139.

Kim, Y., \& Gao, F.Y. (2010). An empirical study of human resource management practices in family firms in China. International Journal of Human Resource Management, 21(12), 2095-2119.

Kotlar, J., \& De Massis, A. (2013). Goal setting in family firms: Goal diversity, social interactions, and collective commitment to family-centered goals. Entrepreneurship Theory and Practice, 37(6), 1263-1288.

KPMG (2017) European family business barometer. $6^{\text {th }}$ edition [online]. Retrieved March 6 , 2018, from https://home.kpmg.com/xx/en/home/insights/2017/11/european-family$\underline{\text { business-barometer-confidence-in-unity-sixth-edition.html }}$

Kramer, R.M. (1999). Trust and distrust in organizations: Emerging perspectives, enduring questions. Annual review of psychology, 50(1), 569-598.

Le Breton-Miller, L., \& Miller, D. (2008). Why do some family businesses out-compete? Governance, longterm orientations, and sustainable capability. Entrepreneurship Theory and Practice, 30(6), 731-746.

Linstead, S., Maréchal, G., \& Griffin, R.W. (2014). Theorizing and researching the dark side of organization. Organization Studies, 35(2), 165-188.

Lubatkin, M.H., Ling, Y., \& Schulze, W.S. (2007). An organizational justice-based view of self-control and agency costs in family firms. Journal of Management Studies, 44(6), 955971.

Madison, K., Daspit, J.J., Turner, K., \& Kellermanns, F.W. (2018). Family firm human resource practices: Investigating the effects of professionalization and bifurcation bias on performance. Journal of Business Research, 84, 327-336. 
Mandl, I. (2008) Overview of family business relevant issues. A report conducted on behalf of the European Commission, Enterprise and Industry Directorate-General [online]. Retrieved March 6, 2018, from http://ec.europa.eu/DocsRoom/documents/10389

Mankelow, G. (2008). Social responsibility paradox of small business human resource management practices. International Journal of Human Resource Management, 19(12), $2171-2181$

Marler, L.E., \& Stanley, L.J. (2018). Who Are Your Friends? The Influence of Identification and Family In-Group and Out-Group Friendships on Nonfamily Employee OCB and Deviance. Entrepreneurship Theory and Practice, 42(2), 310-316.

Mitchell, R.K., Morse, E.A., \& Sharma, P. (2003). The transacting cognitions of nonfamily employees in the family businesses setting. Journal of Business Venturing, 18(4), 533-551.

Morck, R., \& Yeung, B. (2004). Family control and the rent-seeking society. Entrepreneurship Theory and Practice, 28(4), 391-409.

Neckebrouck, J., Schulze, W., Zellweger, T. (2018) Are family firms good employers? Academy of Management Journal, amj.2016.0765

Newman, A., Miao, Q., Hofman, P.S., \& Zhu, C.J. (2016). The impact of socially responsible human resource management on employees' organizational citizenship behaviour: the mediating role of organizational identification. International Journal of Human Resource Management, 27(4), 440-455.

Nkomo, S.M., \& Stewart, M.M. (2006). Diverse identities in organizations. In: S.R. Clegg, S. Hardy, T.B. Lawrence, \& W.R. Nord, The SAGE Handbook of Organization Studies $\left(2^{\text {nd }}\right.$ ed.), London: SAGE Publications Ltd., 520-540.

Poza, E. J., Hanlon, S., \& Kishida, R. (2004). Does the family business interaction factor represent a resource or a cost?. Family Business Review, 17(2), 99-118. 
PWC (2016) Family Business Survey 2016 [online]. Retrieved March 6, 2018, from https://www.pwc.com/gx/en/services/family-business/family-business-survey-2016.html

Ramos, H.M., Man, T.W.Y., Mustafa, M., \& Ng, Z.Z. (2014). Psychological ownership in small family firms: family and non-family employees' work attitudes and behaviours. Journal of Family Business Strategy, 5(3), 300-311.

Reid, R.S., \& Adams, J.S. (2001). Human resource management-a survey of practices within family and non-family firms. Journal of European Industrial Training, 25(6), 310-320.

Riketta, M. (2005). Organizational identification: A meta-analysis. Journal of vocational behavior, 66(2), 358-384.

Sánchez-Marín, G., Meroño-Cerdán, Á.L., \& Carrasco-Hernández, A.J. (2017). Formalized HR practices and firm performance: an empirical comparison of family and non-family firms. International Journal of Human Resource Management, doi/10.1080/09585192.2017.1289547

Schmid, W.T. (2015). Moral Education in Plato's Republic. GSTF Journal of General Philosophy (JPhilo), 1(1).

Schmidts, T., \& Shepherd, D. (2013). Social identity theory and the family business: a contribution to understanding family business dynamics. Small Enterprise Research, 20(2), 76-86.

Schulze, W.S., Lubatkin, M.H., \& Dino, R.N. (2003). Towards a theory of agency and altruism in family firms. Journal of Business Venturing, 18(4), 473-490.

Sieger, P., Bernhard, F., \& Frey, U. (2011). Affective commitment and job satisfaction among non-family employees: investigating the roles of justice perceptions and psychological ownership. Journal of Family Business Strategy, 2(2), 78-89. 
Sorenson, R.L., Goodpaster, K.E., Hedberg, P.R., \& Yu, A. (2009). The family point of view, family social capital, and firm performance: An exploratory test. Family Business Review, 22(3), 239-253.

Stamm, I., \& Lubinski, C. (2011). Crossroads of family business research and firm demography - A critical assessment of family business survival rates. Journal of Family Business Strategy, 2(3), 117-127.

Stets, J. E., \& Burke, P. J. (2000) Identity theory and social identity theory. Social Psychology Quarterly, 63(3), 224-237.

Sundaramurthy, C., \& Kreiner, G.E. (2008). Governing by managing identity boundaries: The case of family businesses. Entrepreneurship Theory and Practice, 32(3), 415-436.

Sveningsson, S., \& Alvesson, M. (2003). Managing managerial identities: Organizational fragmentation, discourse and identity struggle. Human Relations, 56(10), 1163-1193.

Tabor, W., Chrisman, J.J., Madison, K., \& Vardaman, J.M. (2018). Nonfamily members in family firms: A review and future research agenda. Family Business Review, 31(1), 54-79.

Tajfel, H., \& Turner, J.C. (1985). The social identity theory of intergroup behavior. In: S. Worchel \& W. G. Austin (Eds.), Psychology of Intergroup Relations (2 ${ }^{\text {nd }}$ ed., 7-24). Chicago: Nelson-Hall.

Tsao, C.W., Newman, A., Chen, S.J., \& Wang, M.J. (2016). HRM retrenchment practices and firm performance in times of economic downturn: exploring the moderating effects of family involvement in management. International Journal of Human Resource Management, 27(9), 954-973.

Turner, J.C., \& Reynolds, K.J. (2004). The social identity perspective in intergroup relations: Theories, themes, and controversies. In: R. Brown, S. Gaertner (eds.), Self and Social Identity, London: Wiley. 259-277. 
Van der Hayden, L., Blondel, C., \& Carlock, R.S. (2005). Fair process: striving for justice in family business. Family Business Review, 18(1), 1-21.

Vandekerkhof, P., Steijvers, T., Hendriks, W., \& Voordeckers, W. (2015). The effect of organizational characteristics on the appointment of nonfamily managers in private family firms: the moderating role of socioemotional wealth. Family Business Review, 28(2), 104122.

Vardaman, J.M., Allen, D.G., \& Rogers, B.L. (2018). We are friends but are we family? Organizational identification and nonfamily employee turnover. Entrepreneurship Theory and Practice, 42(2), 290-309.

Verbeke, A., \& Kano, L. (2012). The transaction cost economics theory of the family firm: Family-based human asset specificity and the bifurcation bias. Entrepreneurship Theory and Practice, 36(6), 1183-1205.

Voss, Z.G., Cable, D.M., \& Voss, G.B. (2006). Organizational identity and firm performance: What happens when leaders disagree about "who we are?". Organization Science, 17(6), $741-755$

Watson, T.J. (2008). Managing identity: Identity work, personal predicaments and structural circumstances. Organization, 15(1), 121-143.

Westhead, P., \& Howorth, C. (2006). Ownership and management issues associated with family firm performance and company objectives. Family Business Review, 19(4), 301-316.

Westhead, P., \& Howorth, C. (2007). 'Types' of private family firms: an exploratory conceptual and empirical analysis. Entrepreneurship and Regional Development, 19(5), 405-431.

Whetten, D., Foreman, P., \& Dyer, W.G. (2014). Organisational identity and family business. In: L. Melin; M. Nordqvist; P. Sharma (eds.). The SAGE Handbook of Family Business. London: SAGE Publications Ltd., 480-498.

Wiseman, J.P. (1974). The research web, Journal of Contemporary Ethnography, 3(3), 317. 
Xi, J., Kraus, S., Filser, M., \& Kellermanns, F.W. (2014). Mapping the field of family business research: past trends and future directions. International Entrepreneurship and Management Journal, 11(1), 113-132.

Zellweger, T.M., Eddlesteon, K.A., \& Kellermanns, F.W. (2010). Exploring the concept of familiness: introducing family firm identity. Journal of Family Business Strategy, 1, 54-63.

Zellweger, T.M., Nason, R.S., Nordqvist, M., \& Brush, C.G. (2013). Why do family firms strive for nonfinancial goals? An organizational identity perspective. Entrepreneurship Theory and Practice, 37(2), 229-248.

Zellweger, T.M.,Nason, R.S., \& Nordqvist,M. (2012). From longevity of firms to transgenerational entrepreneurship of families: Introducing family entrepreneurial orientation. Family Business Review, 25(2), 136-155.

Zikic, J., \& Richardson, J. (2016). What happens when you can't be who you are: Professional identity at the institutional periphery. Human Relations, 69(1), 139-168. 